\title{
Bioefficacy of Alstonia boonei leaf extract against cowpea beetle Callosobrochus maculatus infesting stored cowpea seeds in storage
}

\section{Kayode David Ileke ${ }^{1}$ and Arotolu Temitope Emmanuel ${ }^{1,2}$}

${ }^{1}$ Department of Biology. Federal University of Technology Akure. Nigeria. Email: kayodeileke@yahoo.com.

${ }^{2}$ Centre of Conservation Medicine and Ecological safety, Northeast Forestry University, Harbin P.R. China. Email: temitopearotolu@yahoo.com.

\begin{abstract}
This study was conducted to investigate the efficacy of the oils of Alstonia boonei leaf extracted with n-hexane, petroleum ether, methane and acetone as contact insecticides against the activities of Callosobrochus maculatus in stored cowpea seed. The oils were incorporated at rates $2.0 \mathrm{~mL}$ per $20 \mathrm{~g}$ of cowpea seeds. The parameters assessed include, mortality of adult insects, oviposition and adult emergence to ascertain the control of the beetle. All concentration of the extracts used evoked $100 \%$ mortality of $C$. maculatus after $72 \mathrm{~h}$ of post treatment. The development of Callosobrochus maculatus was inversely proportional to the concentration of the oil. As the ratio of Alstonia boonei leaf oil extract increased, the mortality of the beetle increased. Therefore, complete protection of seeds and complete inhibition of adult emergence in the oils extracts of Alstonia boonei leaf were effective in controlling cowpea bruchid in stored cowpea seed.
\end{abstract}

Keywords: Alstonia boonei; Leaf oil extracts; Cowpea seed; Callosobrochus maculates; Seed protection.

\section{Introduction}

Cowpea Vigna unguiculata L. (Walp), is an important crop in the tropics especially in West Africa where it is a cheap source of dietary protein (Boeke et al., 2004). Cowpea is widely cultivated and consumed in Nigeria; the
Received

October 5, 2018

Accepted

December 23, 2018

Released

December 31, 2018

Full Text Article

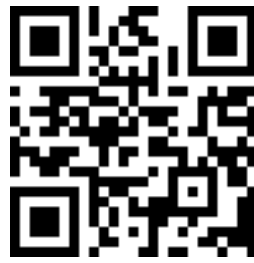

$$
\begin{aligned}
& \text { ORCID } \\
& \text { 0000-0002-3106-4328 } \\
& \text { Kayode David Ileke } \\
& \text { 0000-0003-1330-0160 } \\
& \text { Arotolu Temitope } \\
& \text { Emmanuel }
\end{aligned}
$$

most important producing areas in Nigeria are located in the savanna (Agboola, 1979). According to Blade et al. (1997), Nigeria accounts for $70 \%$ of the world's production. Cowpea is an extremely valuable crop both as a source of revenue and an important source of cheap dietary protein for the third world 
where meat is expensive (Ileke and Olotuah, 2012). High protein and lysine contents of cowpea make it a natural supplement to staple diets of cereals, roots, tuber and fruits (Bressani, 1985). In Nigeria, the production of cowpea is carried out largely by peasant farmers and cowpea production is limited by insect pests which cause serious postharvest losses to the cowpea grain. The value of cowpea lies in its high protein content and ability to tolerate drought and also its compatibility as an intercrop with maize, millet, sorghum, sugarcane and cotton (Caswell, 1984). This makes the grain legumes an important component of traditional intercropping systems especially in the complex and elegant subsistence farming systems of the dry savanna in sub-Saharan Africa.

Cowpea bruchid, Callosobruchus maculatus depreciates stored cowpea (Jackai and Adalla 1997). The huge postharvest losses and quality deterioration caused by this insect pest are threat to food security in a developing nation like Nigeria (Boeke et al., 2004).

The infestation of cowpea seeds by Callosobrochus maculates (F.) accounted for the major loss of cowpea both in store and at fields (Adedire, 2001; Udo, 2005). The females of the bruchid lay their eggs on the seed surface which hatch into larvae within 5 days. The larvae bore through the seed coat into the underlying cotyledons where development continues until adult emergence; the adults are already sexually mature on emergence (Credland and Wright, 1989; Ofuya and Credland, 1995).

Effective and efficient controls of storage insect pests are centered mainly on synthetic insecticides. The use of these synthetic chemicals is hampered by many attendant problems like development of resistance insect strain, toxic residues in foods and humans; workers safety and high cost of procurements (Adedire and Lajide 2001, Ileke and Oni, 2011, Ileke and Olotuah, 2012). These have necessitated research on the use of alternative eco-friendly insect pest control methods among which are the use of plant products (Ileke and Oni, 2011). Lale (1995) reported that plants materials and local traditional methods are safer than synthetic insecticides and suggested that their use needed exploitation. Small scale farmers in the tropics have reported the need to protect cowpea against pest damage during storage (Lale, 1995; Golob et al., 1999). The potential of using plant products such as leaf, bark, root powder from certain plants such as Capsicum spp, Piper spp, and citrus peels have been investigated by Rajapakse and Van Emden (1997) and Ileke and Bolus (2012).

Alstonia boonei De wild is a medicinal plant of West and Central African origin which is extensively used for the treatment of malaria fever, intestinal helminthes, snake bite, arrow, impotence, toothache and oedema (Terashima, 2003; Akinmoladun et al., 2007). The various ethnomedical, chemical, pharmacological and toxicological properties of Alstonia boonei were recently reviewed and the profile further revealed that it is useful in the treatment and management of several illnesses (Adotey et al., 2012). In spite of its vast acceptability as a medicinal plant, the insecticidal potential of $A$. boonei has not been fully explored compared to other botanicals used in storage. The objectives of this study is to investigate the efficacy of $A$. boonei leaf extract against the biological activities of Callosobruchus maculatus in storage.

\section{Materials and method}

\section{Insect cultures}

The starter culture of Callosobruchus maculatus was obtained from an infested cowpea seeds at Environmental Biology and Fisheries laboratory, Adekunle Ajasin University, Akungba Akoko, Nigeria. The cowpea were first sorted to eliminate stones, chaff and other unwanted material, and 
were later disinfected by keeping them in a freezer at $-5{ }^{\circ} \mathrm{C}$ for 7 days. The disinfected seeds were then air dried in the laboratory to prevent mouldiness before the introduction of insects from infected ones (Adedire et al., 2011). They were placed in kilner jars and covered with muslin cloth. The jars were placed in insect rearing cages at ambient temperature of $30 \pm 3{ }^{\circ} \mathrm{C}$ and $70 \% \pm 5 \%$ relative humidity.

\section{Plant collection}

Fresh leaves of Alstonia boonei were collected once from Ijiro, Ilasa Ekiti, Ekiti State. The plant leaves were air dried in an open laboratory and ground into very fine powder using an electric blender (Supermaster, Model SMB 2977, Japan). The powders were further sieved to pass through $1 \mathrm{~mm}^{2}$ perforations prior to storage in a plastic with tight lids in a refrigerator at $4{ }^{\circ} \mathrm{C}$ before use (Ileke and Oni, 2011).

\section{Oil extract}

Extracts of Alstonia boonei was carried out using cold extraction method. About $250 \mathrm{~g}$ of $A$. boonei powders were soaked separately in an extraction bottle containing absolute acetone, petroleum ether, methanol and N-hexane. The mixture was stirred occasionally with a glass rod and extraction was terminated after $72 \mathrm{~h}$. Filteration was carried out using a double layer of Whatman No. 1 filter paper and solvent evaporated using a rotary evaporator at $30^{\circ} \mathrm{C}$ to $40{ }^{\circ} \mathrm{C}$ with rotary speed of 3 to $6 \mathrm{rpm}$ for $8 \mathrm{~h}$ (Ileke and Olotuah, 2012). The resulting extract was air dried in order to remove traces of solvents.

\section{Toxicity of $A$. boonei leaf oil extract on mortality, oviposition, adult emergence of Callosobruchus maculatus, weight loss, damage and weevil perforation index of cowpea seed}

The toxic effect of plants oil on adult C. maculatus was accomplished using $250 \mathrm{~mL}$ plastic containers containing $20 \mathrm{~g}$ of cowpea seeds with concentration of $2 \mathrm{~mL}$ of solvent extract of Alstonia boonei leaf. The oil and seeds were thoroughly mixed with the aid of a glass rod and agitated for 5-10 min to ensure uniform coating. The containers were left open for $30 \mathrm{~min}$ so as to allow trace of solvent to evaporate off. Ten copulating pairs of $C$. maculatus were introduced into the container and mortality was observed daily for 4 days. Cowpea seeds that were solvent treated served as the control experiment (Arannilewa et al., 2006). Similar preparation was set up for Alstonia boonei leaf extracted with N-hexane, petroleum ether and methanol. Three replicates per treatment were prepared. The adult mortality was assessed every $24 \mathrm{~h}$ for $96 \mathrm{~h}$. Adult insects were considered dead where no response was observed after probing them with forcepts. After $96 \mathrm{~h}$, all insects both dead and alive were then removed. Number of eggs laid in each container was counted and recorded.

Progeny emergence (F1) was then recorded at 6 weeks. The containers were sieved out and newly emerged adult bruchid were counted with an aspirator. The percentage adult emergence was calculated according to the method described by Odeyemi and Daramola (2000):

$$
\% \text { Adult emergence }=\frac{\text { No of adults emerged }}{\text { No of eggs laid }} \quad \times 100
$$


The cowpea were re-weighed by using Metler weighing balance and percentege loss in weight was determined as described by Odeyemi and Daramola (2000):

$$
\% \text { Weight loss }=\frac{\text { Difference in weight }}{\text { Initial weight }} \times 100
$$

After re-weighing, the numbers of damaged cowpea seeds were evaluated by counting wholesome and bored or seed with bruchid emergent holes. Percentage seed damaged was calculated according to the method described by Ileke and Olotuah (2012) as follows:

$$
\% \text { seed damage }=\frac{\text { Number of seeds damaged }}{\text { Total number of seeds }} \times 100
$$

Weevil Perforation Index (WPI) were adopted from the analysis of damage using the method of Adedire and
Ajayi (1996). The weevil perforation is defined as follows:

$$
\mathrm{WPI}=\frac{\% \text { treated cowpea seeds perforated }}{\% \text { control cowpea seeds perforated }} \times 100
$$

\section{Statistical analysis}

Data were subjected to analysis of variance (ANOVA) in SPSS 21.0 software and treatment means were separated using the New Duncan's Multiple Range Test.

\section{Results}

\section{Effects of Alstonia boonei leaf extracts on adult mortality of Callosobruchus maculatus (F.)}

Table 1 shows the mortality rate of $C$. maculatus in $20 \mathrm{~g}$ of cowpea seeds treated with $2 \mathrm{~mL}$ of Alstonia boonei oil extracts. The effect of $\mathrm{N}$-hexane was significantly $(\mathrm{P}>0.05)$ higher at $24 \mathrm{~h}$ on mortality rate of $C$. maculatus and $72 \mathrm{~h}$ in all the cowpea seeds treated with $2 \mathrm{~mL}$ of leaf oils. At $24 \mathrm{~h}$ post treatment with $2 \mathrm{~mL}$ of extracts, the percentage mortality were $60 \%, 33 \%, 53 \%, 33 \%$, $50 \%, 30 \%$, and $0 \%$, with N-hexane pet ether, acetone, methanol, and control, respectively. At $48 \mathrm{~h}$ the percentage mortality rate increases to $80 \%, 76.67 \%$, $70 \%, 53.33 \%, 0 \%$, in $\mathrm{N}$-hexane, petether, acetone and methanol, respectively, without any mortality in the control experiment while at $72 \mathrm{~h}$ post treatment, there was an increase in the percentage mortality. The percentage mortality rate at $96 \mathrm{~h}$ of post treatment was $100 \%$ in all treatment. The mortality rate of adult $C$. maculatus in the control was significantly higher than those in cowpea seeds treated Alstonia boonei oil. $\mathrm{N}$-hexane extract of $A$. boonei leaf was observed to have the highest mortality effect on C. maculatus. The control was significantly higher than those in cowpea seeds treated with other oils. 
Table 1. Mortality of adult $C$. maculatus in cowpea seeds treated with different solvents of Alstonia boonei.

\begin{tabular}{lcccc}
\hline \multirow{2}{*}{ Alstonia boonei leaf extract } & \multicolumn{4}{c}{ \% mortality at hours post treatment } \\
\cline { 2 - 5 } & $\mathbf{2 4}$ & $\mathbf{4 8}$ & $\mathbf{7 2}$ & $\mathbf{9 6}$ \\
\hline N-hexane & $60.33 \pm 001^{\mathrm{c}}$ & $80.00 \pm 0.00^{\mathrm{d}}$ & $100.00 \pm 0.00^{\mathrm{c}}$ & $100.00 \pm 0.00^{\mathrm{b}}$ \\
Petroleum-ether & $53.33 \pm 0.01^{\mathrm{bc}}$ & $76.67 \pm 0.04^{\mathrm{cd}}$ & $100.00 \pm 0.00^{\mathrm{c}}$ & $100.00 \pm 0.00^{\mathrm{b}}$ \\
Acetone & $50.00 \pm 0.00^{\mathrm{bc}}$ & $70.00 \pm 0.00^{\mathrm{c}}$ & $100.00 \pm 0.00^{\mathrm{c}}$ & $100.00 \pm 0.00^{\mathrm{b}}$ \\
Methanol & $30.00 \pm 0.00^{\mathrm{b}}$ & $53.33 \pm 0.01^{\mathrm{b}}$ & $80.00 \pm 0.00^{\mathrm{b}}$ & $100.00 \pm 0.00^{\mathrm{b}}$ \\
Control & $0.00 \pm 0.00^{\mathrm{a}}$ & $0.00 \pm 0.00^{\mathrm{a}}$ & $0.00 \pm 0.00^{\mathrm{a}}$ & $0.00 \pm 0.00^{\mathrm{a}}$ \\
\hline
\end{tabular}

Each value is a mean \pm standard error of three replicates. Means within the same column followed by the same letter(s) are not significantly different at $\mathrm{p}>0.05$ using New Duncan Multiple Range Test.

\section{Effect of Alstonia boonei leaf extracts on oviposition and adult emergence of Callosobruchus maculatus (F.)}

The number of eggs laid by adult C. maculatus varied with $A$. boonei leaf extract used and the concentration of the extracts added to the cowpea seeds, (Table 2). The mean number of egg oviposition by adult $C$. maculatus where $10.00,10.33,10.00,23.33$ and 87.67 in leaf extracted with n-hexane, pet ether, acetone, methanol and control respectively. The number of eggs laid in cowpea seeds treated with methanol leaf extracts while control having the highest number of eggs. There was a reduction in the numbers of eggs laid in cowpea seeds treated with n-hexane leaf extracts which proves to be the most effective among other treatments.

Table 2. Effects of Alstonia boonei leaf extracts on oviposition and adult emergence of Callosobruchus maculatus.

\begin{tabular}{lcc}
\hline Alstonia boonei extracts & No. of eggs laid (oviposition) & \% Adult emergence \\
\hline n-hexane & $10.00 \pm 0.00^{\mathrm{a}}$ & $0.00 \pm 0.00^{\mathrm{a}}$ \\
Petroleum-ether & $10.33 \pm 0.01^{\mathrm{a}}$ & $0.00 \pm 0.00^{\mathrm{a}}$ \\
Acetone & $10.00 \pm 0.01^{\mathrm{a}}$ & $0.00 \pm 0.00^{\mathrm{a}}$ \\
Methanol & $23.33 \pm 0.01^{\mathrm{b}}$ & $0.00 \pm 0.00^{\mathrm{a}}$ \\
Control & $87.67 \pm 0.04^{\mathrm{c}}$ & $85.28 \pm 0.11^{\mathrm{b}}$ \\
\hline
\end{tabular}

Each value is a mean \pm standard error of three replicates. Means within the same column followed by the same letter(s) are not significantly different at $p>0.05$ using New Duncan Multiple Range Test.

There were no adult emergences of $C$. maculatus in all the treated cowpea seeds. The numbers of adult emerged in cowpea seeds treated with various Alstonia boonei leaf extracts was lower $(\mathrm{p}<0.05)$ when compared with number of adult emerged in cowpea seeds in control that recorded $85.28 \%$.

\author{
Effect of Alstonia boonei leaf oil \\ on short term storage of cowpea seeds \\ The mean percentage numbers of \\ cowpea seeds by different oil extracts are \\ significantly different (Table 3). The \\ mean percentage damage by \\ C. maculatus on cowpea seeds were not
}


significantly different with the oil extracts of Alstonia boonei leaf except the control which have high number of seed damaged. The four oil extracts with nhexane, pet ether, acetone and methanol from Alstonia boonei leaf are more effective in reducing the weight loss. The weevil perforation index (WPI) of C. maculatus on cowpea seeds with leaf oil extracts of $A$. boonei with different solvent were good protectant (less than 50) while control is not a good protectant $(50.00 \pm 0.00)$.

Table 3. Effect of Alstonia boonei leaf oil on short term storage of cowpea seeds.

\begin{tabular}{lccccc}
\hline $\begin{array}{c}\text { 0.5\% v/w A. } \\
\text { boonei extracts }\end{array}$ & $\begin{array}{c}\text { Mean total } \\
\text { number of } \\
\text { seeds }\end{array}$ & $\begin{array}{c}\text { Mean } \\
\text { number of } \\
\text { damaged } \\
\text { seeds }\end{array}$ & $\begin{array}{c}\text { Mean \% } \\
\text { seed } \\
\text { damage }\end{array}$ & $\begin{array}{c}\text { Mean } \\
\text { weight loss }\end{array}$ & $\begin{array}{c}\text { Weevil } \\
\text { perforation } \\
\text { index }\end{array}$ \\
\hline n-hexane & 93.67 & $0.00 \pm 0.00^{\mathrm{a}}$ & $0.00 \pm 0.00^{\mathrm{a}}$ & $0.00 \pm 0.00^{\mathrm{a}}$ & $0.00 \pm 0.00^{\mathrm{a}}$ \\
Petroleum-ether & 95.00 & $0.00 \pm 0.00^{\mathrm{a}}$ & $0.00 \pm 0.00^{\mathrm{a}}$ & $0.00 \pm 0.00^{\mathrm{a}}$ & $0.00 \pm 0.00^{\mathrm{a}}$ \\
Acetone & 91.33 & $0.00 \pm 0.00^{\mathrm{a}}$ & $0.00 \pm 0.00^{\mathrm{a}}$ & $0.00 \pm 0.00^{\mathrm{a}}$ & $0.00 \pm 0.00^{\mathrm{a}}$ \\
Methanol & 95.33 & $0.00 \pm 0.00^{\mathrm{a}}$ & $0.00 \pm 0.00^{\mathrm{a}}$ & $0.00 \pm 0.00^{\mathrm{a}}$ & $0.00 \pm 0.00^{\mathrm{a}}$ \\
Control & 93.33 & $86.67 \pm 0.01^{\mathrm{b}}$ & $92.86 \pm 0.14^{\mathrm{b}}$ & $11.02 \pm 0.01^{\mathrm{b}}$ & $50.00 \pm 0.00^{\mathrm{b}}$ \\
\hline
\end{tabular}

Each value is a mean \pm standard error of three replicates. Means within the same column followed by the same letter(s) are not significantly different at $p>0.05$ using New Duncan Multiple Range Test.

\section{Discussion}

The resultant high mortalities of adults $C$. maculatus observed on cowpea treated with $A$. boonei leaf oil extracts could be due to high toxic effect of the product on adult $C$. maculatus. The A. boonei leaf oil extracts also prevented the emergence of $C$. maculatus adults, an effect that is in agreement with the observation of Osawe et al. (2007) who reported that the aqueous extracts of the stem bark and leaves of this plant adversely affected the survival and growth of Sesamia calamists. The results show that the leaf oil extracted with nhexane, pet ether, acetone and methanol had varied degrees of effects on C. maculatus at $24 \mathrm{~h}, 48 \mathrm{~h}, 72 \mathrm{~h}$ and $96 \mathrm{~h}$ of post treatment. This study demonstrated that $A$. boonei oil is toxic to adults and eggs of $C$. maculatus. This is in agreement with the report of Daniel (1991) who reported that plant oils are toxic to young larval, adults and eggs of C. maculatus. Petroleum-ether and acetone oil extracts treatment on cowpea seeds show some degree effects against C. maculatus on oviposition and adult emergence but not as high as that of n-hexane leaf oil treatment which has highest degree of effect. This confirm the report of Benner (1993) who reported that extractions of insecticidal plants powders with appropriate solvent, often concentrates the active minerals and make their potency readily detectable.

In this study, the lethal effect of these oil extracts on cowpea beetle could be as a result of contact toxicity. Most insects breathe by means of trachea which usually opens at a surface of the body through spiracles (Adedire et al., 2011; Ileke and Olotuah, 2012). This spiracle must have been blocked by the oil extracts thereby leading to suffocation of the insects. The oils on application disrupt mating and sexual communication as well as deterring female from laying eggs (NRC, 1992). Also, on application to cowpea seeds, the oil covered the testa of the grains, 
serving as food poison to the adult's insects; while some of them penetrated into the endosperm and germ layer thereby suppressing oviposition and larval development. The non-protectant control had no effect on the mortality; oviposition and adult emergence of C. maculatus may be attributed to interference with normal respiration resulting in suffocation (Hall and Harman 1991). Out of the four solvents used, acetone has been found to give highest mean value, with no or low number of adult emergence in n-hexane. The lower the mean value observed, the more effective the solvent of leaf oil, n-hexane oil extract from the leaf at different concentration is the most effective on adult emergence of $C$. maculatus.

\section{Conclusion}

This study revealed the bioefficacy of Alstonia boonei lesf extract against cowpea beetle Callosobruchus maculatus infesting stored cowpea seeds in storage. Effective and efficient controls of storage insect pests are centered mainly on synthetic insecticides. The use of these synthetic chemicals is hampered by many attendant problems. These have necessitated research on the use of alternative eco-friendly insect pest control methods among which are the use of plant products. The plant (Alstonia boonei) is readily available, and has not been reported to be toxic to man. Therefore, this study suggest that Alstonia boonei leaf oil can be used as biopesticides against cowpea beetles in storage.

\section{Acknowledgements}

We are thankful for the dedicated support by the technologists in the Federal University of Technology Akure Research laboratory for our research, most especially Mrs T. Ojo. We also thank the people who accompanied us to procure the plant leaves.

\section{Conflicts of interest}

Authors declare that they have no conflict of interests.

\section{References}

Adedire, C. O. Use of nutmeg Myristica fragrans (Houtt.) powder and oil for the control of cowpea storage bruchid, $C$. maculatus (p.). Journal of Plant Diseases and Protection, v. 109, p. 193-199, 2002.

Adedire, C. O.; Ajayi, T. S. Assessment of the insecticidal properties of some plant extracts as grain protection against the maize weevil, Sitophilus zeamais. Nigerian Journal of Entomology, v. 13, p. 93-101, 1996.

Adedire, C. 0.; Ajayi, O. E. Insecticidal activity of under-utilized tropical plant seed oil, Hura crepitans L. on cowpea seed beetle, Callosobruchus maculatus (F.) (Coleoptera: Bruchidae). Nigeria Journal of Entomology, v. 20, p. 74-81, 2003.

Adedire, C. 0.; Obembe, 0. 0.; Akinkurolere, R. O.; Oduleye, O. Response of Callosobruchus maculatus (Coleoptera: Chysomelidae: Bruchidae) to extract of cashew kernels. Journal of Plant Diseases and Protection, v. $118, \quad$ no. $2, \quad$ p. $75-79, \quad 2011$. https://doi.org/10.1007/BF03356385

Adedire, C. O.; Lajide, L. Efficacy of powders of some plants in the control of the pulse beetle, Callosobruchus maculatus (F.) (Coleoptera: Bruchidae). Journal of Applied Tropical Agriculture, v. 6, p. 11-15, 2001.

Adotey, J. P. K.; Adukpo, G. E.; Opoku Boahen, Y; Armah, F. A. A review of the ethnobotany and pharmacological importance of Alstonia boonei De Wild (Apocynaceae). ISRN Pharmacology, v. 2012, Article ID 587160, $2012 . \quad$ https://doi.org/10.5402/2012/ 587160

Agboola, S.A. An agricultural atlas of Nigeria. London: Oxford University Press, 1997.

Akinmoladun, A. C.; Ibukun, E. O.; Afor, E.; Akinrinlola, B. L.; Onibon, T. R.; Akinboboye, A. O.; Obuotor, E. M.; Farombi, E. O. Chemical constituents and antioxidant activity of Alstonia boonei. African Journal of Biotechnology, v. 6 , no. 10, p. 1197-1201, 2007. 
Alzouma, I. Observations on the ecology of Bruchidius atrolincatus Pie and Callosobruchus maculatus (F.) in Niger. In: Labeyire, V. (Ed.). The ecology of bruchids attacking legumes. The Hague, Junk, 1981. p. 205-213.

Arannilewa, S. T.; Ekrakene, T.; Akinneye, J. 0. Laboratory evaluation of four medicinal plants as protection against the maize weevil, Sitophilus zeamais. African Journal of Biotechnology, v. 5, no. 21, p. 2032-2036, 2006.

Banner, N.; Gupta, D. F.; Ram, S. Effect of vegetable oils on the ovipositional behaviour of Callosobruchus maculatus (F.). In: Fujii, K.; Gatehouse, A. M. R.; Johnson, C. D.; Mitchell, R.; Oshida, T.Y (Eds.). Bruchids and legumes: Economics, ecology and coevolution. Dordrecht: Kluwer Academic Publishers, 1990. p. 88-84.

Benner, J.P. Pesticidal compounds from higher plants. Pesticide Science, v. 39, p. 95122, 1993.

Blade, S. F.; Shetty, R. V. S.; Terao, T.; Singh, B. B. Recent developments in cowpea cropping systems research. In: Singh, B. B.; Mohan Raj, D. R.; Dashiell, K. E.; Jackai, L. E. N. (Eds.). Advances in cowpea research. Ibadan, Nigeria: IITA, JIRCAS, 1997. p. 114-128.

Boeke, S. J.; Barnaud, C.; Van Loon, J. J. A.; Kossou, D. K..; Van Huis, A.; Dicke, M. Efficacy of plant extracts against the cowpea bettle, Callosobruchus maculatus. International Journal of Pest Management, v. 50, no. 4, p. 251-258, 2004.

Bressani, R. Nutritive value of cowpea. In: Sangh, S. R.; Rachie, K. (Eds.). Cowpea research production and utilization. New York: John Wiley and Sons, 1985. p 335-359.

Caswell, G.H. The value of the pod in protecting cowpea seed from attack by bruchid beetles. Samaru Jourmal of Agricultural Research, v. 2, p. 49-55, 1984.

Credland, P. F.; Wright, A. W. Factors affecting female fecundity in the cowpea seed beetle, Callosobruchus maculatus (Coleoptera: Bruchidae). Journal of Stored Product Research, v. 25, p. 125-136, 1989.

Daniel, S. H. The use of neem (Azadirachta indica A. Juss) and some plant oils as protectants of cowpea (Vigna unguiculata (L.) Walp) against the cowpea weevil, $C$. maculatus (F.). Reading: University of Reading, 1991. (Ph. D. Thesis).
Golob, P.; Moses, C.; Dales, M.; Fidgen, A.; Evans, J.; Gudrups, I. The use of spices and medicinal as bioactive protectants for grains. Rome: FAO, 1999. (FAO Agricultural Service Bulletin, 137).

Hall, J. S.; Harman, G. E. Protection of stored legume seeds against attack by storage fungi and weevils: Mechanism of action of lipoidal and oil seed treatments. Crop Protection, v. 10, p. 375-380, 1991.

Ileke, K. D.; Bulus, D. S. Evaluation of contact toxicity and fumigant effect of some medicinal plant and Pirimiphos Methyl powders against cowpea bruchid, Callosobruchus maculatus (Fab.) (Coleoptera: ChrysomeIidae) in stored cowpea seeds. Journal of Agricultural Science, v. 4, no. 4, p. 279-284, 2012.

Ileke, K. D.; Olotuah O. F. Bioactivity of Anacardium occidentale (L) and Allium sativum (L) powders and oil extracts against cowpea bruchid, Callosobrochus maculatus (Fab.) (Coleoptera: Chrysomelidae). International Journal of Biology, v. 4, no. 1, p. 96-103, 2012.

Ileke, K. D.; Oni, M. O. Toxicity of some plant powders to maize weevil, Sitophilus zeamais (motschulsky) (Coleoptera: Curculionidae) on the stored wheat grains (Triticum aestivum). African Journal of Agricultural Research, v. 6, no. 13, p. 3040-3048, 2011.

Jackai, L. E. N.; Adalla, C. B. Pest management practice in cowpea. In: Singh, B. B.; Mohan Raj, D. R.; Dashielle, K. E.; Jackai, L. E. N. (Eds.). Advances in cowpea research. Badan, Nigeria: IITA, JIRCAS, 1997. p. 240258.

Lale, N. E. S. An overview of the use of plant products in the management of stored products coleoptera in the tropics. Post Harvest News and Information, v. 6, no. 6, p. 69N-75N, 1995.

NRC - National Research Council. Neem, a tree for solving global problems. Washinton, D. C.: National Academy Press, 1992.

Odeyemi, 0. O.; Daramola, A. M. Storage practices in the tropics: Food storage and pest problems. 1. ed. Nigeria: Dave Collins Publication, 2000.

Ofuya, T. I.; Credland, P. F. Responses of three populations of the seed beetle, Callosobruchus maculatus (F.) (Coleoptera: Bruchidae) to seed resistance in selected 
varieties of cowpea, Vigna unguiculata (L.)

Walp. Journal of Stored Products Research, v. 31, p. 17-27, 1995.

Osawe, N. O.; Igho, B. I.; Manuele, T. Insecticidal activity of the medicinal plant, Alstonia boonei against Sesamia calamistis Hampson. Journal of Zhejiang University Science B, v. 8, no. 10, p. 752-755, 2007. https://doi.org/10.1631/jzus.2007

Rajakse, R.; Van Gnden, H. F. Potential of four vegetable oils and ten botanical powders for reducing infestations of cowpeas by $C$. maculatus, C. chinensis, and C. rhodesianus. Journal of Stored Products Research, v. 33, p. 59-68, 1997.

Terashima, H. N. Use and attribute of plants and animals among the Ituri forest foragers: A comparative ethnobatanical and ethnozoological study. African Study and Monography, v. 28, suppl., p. 7-24, 2003.

Udo, I. O. Evaluation of the potential of some local pices as stored grain protectants against the maize weevil Sitophilus zeamais Motsch (Coleoptera: Curculionidae). Journal of Applied Sciences and Environmental Management, v. 9, p. 165-168, 2005. 